\title{
KEEFEKTIFAN PERANGKAT RENCANA PELAKSANAAN PEMBELAJARAN MELALUI PENELITIAN BERBASIS PERANCANGAN
}

\author{
Noorlatifah $^{1^{*}}$,, Suryajaya ${ }^{2}$, Muhammad Zaini ${ }^{3}$ \\ ${ }^{1}$ Guru SMK Farmasi Mandiri Banjarmasin, Kalimantan Selatan, Indonesia \\ e-mail: latifah.tifah42@gmail.com \\ ${ }^{2}$ Fisika FMIPA Universitas Lambung Mangkurat, Banjarbaru, Indonesia \\ e-mail: suryajaya@gmail.com \\ ${ }^{3}$ Pendidikan Biologi FKIP Universitas Lambung Mangkurat, Banjarmasin, Indonesia \\ e-mail:muhammadzaini@ulm.ac.id
}

$\begin{array}{lll}\text { Submit } & : 11-02-2021 & \text { Revision : 22-03-2021 } \\ \text { Accepted } & : 26-03-2021 & \text { Published : 01-04-2021 }\end{array}$

*Corresponding author: Noorlatifah

\begin{abstract}
Abstrak: Guru masih mengalami kesulitan dalam melatihkan kemampuan berpikir kritis sehingga hasil belajar dan keterampilan berpikir kritis dalam pembelajaran IPA kurang optimal. Penelitian ini bertujuan mengevaluasi keefektifan kualitas perangkat RPP hasil pengembangan menggunakan model pembelajaran inkuiri terbimbing topik perubahan wujud di SMPN 22 Banjarmasin. Metode yang digunakan adalah penelitian pengembangan. Model pengembangan perangkat yang digunakan adalah model Tessmer, meliputi tahap self evaluation, expert review, one to one, small group, dan field test. Perangkat RPP yang dikembangkan adalah silabus, RPP, bahan ajar, LKPD, dan lembar penilaian. Subyek dalam penelitian adalah peserta didik kelas VII SMPN 22 Banjarmasin. Hasil penelitian menunjukkan bahwa perangkat RPP menggunakan model inkuiri terbimbing topik perubahan wujud tergolong efektif meliputi hasil belajar peserta didik dengan persentase ketuntasan sebesar $76 \%$ dan telah mencapai KKM yang ditetapkan sekolah. Keterampilan berpikir kritis peserta didik terkategori sangat baik, keterampilan psikomotor peserta didik menggunakan kertas saring terkategori sangat baik, perilaku berkarakter meliputi aspek disiplin terkategori sangat baik dan aspek tanggung jawab terkategori sangat baik. Keterampilan sosial meliputi aspek bekerja sama terkategori cukup baik, aspek menyumbangkan ide terkategori sangat baik, dan sikap spiritual rasa syukur terkategori sangat baik. Berdasarkan hasil penelitian berikut dapat disimpulkan bahwa perangkat RPP melalui penelitian berbasis perancangan efektif.
\end{abstract}

Kata kunci: keefektifan, perangkat RPP, inkuiri terbimbing, hasil belajar, keterampilan berpikir kritis

\section{THE EFFECTIVENESS OF LEARNING PLAN DEVICES THROUGH DESIGN-BASED RESEARCH}

\begin{abstract}
Teachers still have difficulty practicing critical thinking skills so that learning outcomes and critical thinking skills in science learning are less than optimal. This study aims to evaluate the effectiveness of the quality of the lesson plans developed using a guided inquiry learning model with the topic of change in form at SMPN 22 Banjarmasin. The method used is development research. The device development model used is the Tessmer model, which includes the stages of self-evaluation, expert review, one to one, small group, and field test. The lesson plans developed were syllabus, lesson plans, teaching materials, LKPD, and assessment test. The subjects in the study were students of class VII SMPN 22 Banjarmasin. The results showed that the lesson plan using the guided inquiry model, the topic of change in form was classified as effective, including the learning outcomes of students with a completeness percentage of $76 \%$ and had reached the KKM set by the school. Students 'critical thinking skills are categorized as very good, students' psychomotor skills use very good categorized filter papers, characterized behavior includes disciplinary aspects that are very well categorized and aspects of re-
\end{abstract}


Noorlatifah., Suryajaya., \& Zaini, M. (2021). Keefektifan Perangkat Rencana Pelaksanaan Pembelajaran melalui Penelitian Berbasis Perancangan.

sponsibility are very good. Social skills include aspects of working together which are categorized as quite good, aspects of donating ideas are categorized as very good, and spiritual attitudes of gratitude are categorized as very good. Based on the following research results, it can be concluded that the lesson plan tools through design-based research are effective.

Keywords: effectiveness, lesson plans tools, guided inquiry, learning outcomes, critical thinking skills

\section{PENDAHULUAN}

Pembelajaran IPA dalam kurikulum 2013 mengharuskan peserta didik untuk aktif dan mampu dalam berpikir kritis dan menggunakan langkah-langkah penelitian dalam belajar. Harapan yang diinginkan dari peserta didik tidak hanya belajar untuk mencapai hasil yang baik, tetapi juga dapat mengikuti alur proses belajar secara maksimal (Af'idayani dkk., 2018; Rahayu dkk; 2018). Kemampuan berpikir kritis merupakan salah satu modal yang harus dimiliki peserta didik sebagai bekal dalam menghadapi perkembangan ilmu pengetahuan dan teknologi pada masa sekarang ini (Fahmi dkk., 2019).

Dalam pelaksanaan pembelajaran, guru dituntut untuk bisa membuat dan mengembangkan perangkat pembelajaran IPA secara terpadu. Dalam penerapannya di sekolah, materi IPA bergantung pada kecenderungan materi-materi yang mempunyai potensi untuk dipadukan dalam satu konsep pembelajaran. Pentingnya mengajarkan dan mengembangkan kemampuan berpikir kritis harus dipandang sebagai sesuatu tidak bisa disepelekan lagi. Upaya memfasilitasi agar kemampuan berpikir kritis peserta didik berkembang menjadi sangat penting, mengingat beberapa hasil penelitian masih menunjukkan rendahnya kemampuan berpikir kritis peserta didik (Fahmi, 2016).

Permasalahan dalam kegiatan belajar mengajar yang terdapat di SMPN 22 Banjarmasin menunjukkan peserta didik mengalami kesulitan jika dihadapkan kepada persoalan yang memerlukan kemampuan berpikir kritis sehingga hasil belajar kurang optimal. Guru belum sepenuhnya melatihkan keterampilan berpikir kritis dalam pembelajaran IPA. Selain itu, perangkat RPP yang tersedia masih bersifat pembelajaran berpusat pada guru yang membuat kurangnya partisipasi peserta didik dalam belajar sehingga pembelajaran IPA terkesan membosankan dan membuat peserta didik jenuh atau kurang bersemangat. Pembelajaran IPA yang masih terbilang banyak mengandung konsep abstrak serta rumus-rumus yang harus dipahami oleh peserta didik (Khaerani dkk., 2020). Oleh karena itu, penting bagi guru untuk mengajarkan IPA secara utuh dengan menggunakan tahapan-tahapan proses ilmiah yang dianjurkan di dalam kurikulum 2013.

Upaya meningkatkan kualitas pembelajaran terus dilakukan, diantaranta dengan model pembelajaran inkuiri terbimbing. Dalam Permendikbud Nomor 58 Tahun 2014 dan Permendikbud No. 65 Tahun 2013, tujuan pembelajaran IPA di SMP dilakukan secara inkuiri yaitu untuk menumbuhkan kemampuan berpikir, bersikap dan bertindak secara ilmiah dan berkomunikasi, serta meningkatkan pengetahuan, konsep, dan keterampilan berpikir kritis. Untuk menjalankan hal tersebut, diterapkan pembelajaran berbasis penelitian.

Kemampuan peserta didik didorong untuk menghasilkan karya secara individu maupun kelompok maka sangat disarankan menggunakan pendekatan pembelajaran yang menghasilkan karya menggunakan model inkuiri terbimbing. Dalam belajar bagaimana IPA tersebut ditemukan, peserta didik dibimbing dengan melakukan tahapan-tahapan sintak yang terdapat dalam model inkuiri terbimbing. Faktor tersebutlah yang dapat membantu peserta didik untuk meningkatkan pengetahuan dan keterampilannya di sekolah.

Model inkuiri terbimbing adalah model pembelajaran yang cocok dipakai untuk menggali keterampilan berpikir kritis peserta didik dan meningkatkan hasil belajar. Rahmawati dkk., (2020) menyatakan pembelajaran berbasis inkuiri memberikan peluang kepada peserta didik untuk terus mengembangkan potensi diri secara maksimal baik dari segi kognitif, afektif, maupun psikomotor. Dengan menerapkan model inkuiri, konsep-konsep IPA dibuat sendiri oleh peserta didik, dan juga dilatih untuk mengembangkan keterampilan berpikir kritis, serta dilengkapi dengan kemampuan-kemampuan dalam menyelesaikan masalah.

\section{METODE PENELITIAN}

Penelitian ini dilakukan dalam dua tahap yaitu tahap persiapan dan tahap evaluasi formatif. Evaluasi formatif meliputi self evaluation, expert review, small group, serta field test dalam Tessmer (1998). Subjek penelitian adalah peserta didik kelas VII SMPN 22 Banjarmasin.

Prosedur pengembangan perangkat pembelajaran model Tessmer meliputi tahap self evaluation dilakukan analisis dan desain. Peneliti menganalisis materi pelajaran yang sesuai dengan kurikulum 2013. Desain dilakukan pada perangkat RPP yang dibuat, seperti silabus, RPP disusun dengan memerhatikan sintak model inkuiri terbimbing yang terimplementasi pada kegiatan pembelajaran, LKPD un- 
tuk membantu peserta didik dalam meningkatkan keterampilan berpikir kritis, bahan ajar sebagai sumber belajar, dan lembar penilaian untuk melihat ketercapaian kompetensi dasar dan indikator serta untuk mengetahui pemahaman konsep peserta didik.

Tahap expert review dan one to one dilakukan oleh tim pakar. Kegiatan penelaahan oleh tim pakar bertujuan untuk menilai validitas perangkat RPP hasil pengembangan yang telah dibuat. Tahap small group, bertujuan menilai kepraktisan dari keterlaksanaan RPP terhadap pelajaran. Tahap field test, bertujuan menilai keefektifan perangkat RPP hasil pengembangan yang dibuat dan menentukan ketercapaian tujuan pembelajaran.

Jenis data yang dikumpulkan yakni data keefektifan meliputi hasil belajar kognitif, hasil keterampilan berpikir kritis, keterampilan psikomotor, perilaku berkarakter, keterampilan sosial dan sikap spiritual. Analisis dalam penelitian ini meliputi hasil keefektifan perangkat RPP meliputi skor hasil belajar 4 jika benar dan 0 jika salah, dengan persentase ketuntasan digunakan rumus:

$$
\text { Persentase }=\frac{\text { skor perolehan }}{\text { skor maksimal }} \times 100 \%
$$

Hasil keterampilan berpikir kritis adalah kemampuan dalam melaksanakan tahapan-tahapan percobaan model inkuiri terbimbing, antara lain merumuskan masalah, membuat hipotesis, merancang percobaan, mengumpulkan data, menganalisis data, dan membuat kesimpulan menggunakan rubrik seperti Tabel 1. Rubrik ini juga berlaku untuk mengukur keterampilan berpikir kritis, keterampilan psikomotor, perilaku berkarakter, keterampilan sosial, dan sikap spiritual.

Tabel 1. Rubrik keefektifan perangkat pembelajaran

\begin{tabular}{ccc}
\hline No & Rentang skor nilai & Kategori \\
\hline 1 & $86-100 \%$ & Sangat baik \\
2 & $76-85 \%$ & Baik \\
3 & $60-75 \%$ & Cukup baik \\
4 & $55-59 \%$ & Kurang baik \\
5 & $\leq 54 \%$ & Tidak baik \\
\hline
\end{tabular}

\section{HASIL DAN PEMBAHASAN}

Perangkat pembelajaran yang telah dikembangkan, dilakukan penilaian untuk mengevaluasi keefektifan kualitas perangkat RPP hasil pengembangan menggunakan model pembelajaran inkuiri terbimbing topik perubahan wujud di SMPN 22 Banjarmasin. Keefektifan perangkat RPP diperoleh dari hasil belajar, keterampilan berpikir kritis, keterampilan psikomotor, perilaku berkarakter, keterampilan sosial dan sikap spiritual peserta didik selama pembelajaran berlangsung. Skor hasil belajar peserta didik diperoleh dari hasil belajar kognitifdengan ketuntasan yang telah mencapai KKM yang ditetapkan sekolah yaitu sebesar 75. Ringkasan hasil belajar peserta didik dapat dilihat pada Tabel 2.

Tabel 2. Hasil belajar kognitif

\begin{tabular}{cccccc}
\hline No. & Nama peserta didik & Pretes & Ketuntasan & Postes & Ketuntasan \\
\hline 1 & AA & 32 & TT & 80 & T \\
2 & ANS & 28 & TT & 80 & T \\
3 & AH & 48 & TT & 80 & T \\
4 & AI & 40 & TT & 76 & T \\
5 & AS & 48 & TT & 92 & T \\
6 & BI & 28 & TT & 68 & T \\
7 & BS & 84 & T & 100 & T \\
8 & DL & 52 & TT & 76 & T \\
9 & F & 76 & T & 76 & T \\
10 & GAS & 80 & T & 84 & T \\
11 & HA & 48 & TT & 76 & TT \\
12 & HE & 28 & TT & 56 & T \\
13 & LN & 36 & T & 100 & TT \\
14 & MA & 80 & TT & 56 & T \\
15 & MHR & 32 & TT & 76 & T \\
16 & MRI & 28 & TT & 76 & T
\end{tabular}


Noorlatifah., Suryajaya., \& Zaini, M. (2021). Keefektifan Perangkat Rencana Pelaksanaan Pembelajaran melalui Penelitian Berbasis Perancangan.

\begin{tabular}{|c|c|c|c|c|c|}
\hline 20 & MI & 48 & $\mathrm{TT}$ & 84 & $\mathrm{~T}$ \\
\hline 21 & MNF & 72 & $\mathrm{TT}$ & 84 & $\mathrm{~T}$ \\
\hline 22 & MRS & 68 & $\mathrm{TT}$ & 88 & $\mathrm{~T}$ \\
\hline 23 & MS & 32 & $\mathrm{TT}$ & 76 & $\mathrm{~T}$ \\
\hline 24 & MSA & 36 & $\mathrm{TT}$ & 72 & $\mathrm{TT}$ \\
\hline 25 & $\mathrm{NH}$ & 32 & $\mathrm{TT}$ & 76 & $\mathrm{~T}$ \\
\hline 26 & NY & 28 & $\mathrm{TT}$ & 76 & $\mathrm{~T}$ \\
\hline 27 & $\mathrm{~N}$ & 32 & $\mathrm{TT}$ & 84 & $\mathrm{~T}$ \\
\hline 28 & RA & 88 & $\mathrm{~T}$ & 100 & $\mathrm{~T}$ \\
\hline 29 & RI & 32 & $\mathrm{TT}$ & 52 & $\mathrm{TT}$ \\
\hline 30 & SM & 20 & $\mathrm{TT}$ & 40 & $\mathrm{TT}$ \\
\hline \multicolumn{2}{|c|}{ Jumlah yang tuntas } & 5 & & 23 & \\
\hline \multicolumn{2}{|c|}{$\%$ ketuntasan } & $16 \%$ & & $76 \%$ & \\
\hline
\end{tabular}

Berdasarkan Tabel 2 peserta didik yang sudah tuntas sebanyak 23 orang dengan persentase ketuntasan sebesar 76\% dan telah mencapai KKM yang ditetapkan sekolah yaitu sebesar 75 . Berdasarkan hal tersebut dapat disimpulkan bahwa perangkat RPP dikatakan efektif.

Keterampilan berpikir kritis pada uji lapangan diperoleh dari kegiatan LKPD dalam proses pembelajaran di kelas secara berkelompok yang terbagi dalam 6 kelompok terdiri dari masing-masing 5 peserta didik. Hasil keterampilan berpikir kritis peserta didik dapat dilihat pada Tabel 3.

Tabel 3. Hasil keterampilan berpikir kritis

\begin{tabular}{ccccccc}
\hline & \multicolumn{7}{c}{ Indikator (\%) } \\
& 1 & 2 & 3 & 4 & 5 & 6 \\
\hline P1 & 90 & 90 & 90 & 100 & 92 & 86 \\
P2 & 80 & 90 & 90 & 85 & 88 & 86 \\
P3 & 90 & 80 & 90 & 90 & 84 & 86 \\
Rata-rata & 87 & 87 & 90 & 92 & 88 & 86 \\
\hline Kategori & Sangat baik & Sangat baik & Sangat baik & Sangat baik & Sangat baik & Sangat baik \\
\hline
\end{tabular}

Indikator; 1) merumuskan masalah, 2) membuat hipotesis, 3) merancang percobaan, 4) melakukan percobaan untuk memperoleh informasi 5) mengumpulkan data dan menganalisis data, dan 6) membuat kesimpulan

Berdasarkan Tabel 3 hasil keterampilan berpikir kritis peserta didik pada indikator merumuskan masalah dan membuat hipotesis, merancang percobaan, melakukan percobaan untuk memperoleh informasi, mengumpulkan data dan menganalisis data, serta membuat kesimpulan terkategori sangat baik. Berdasarkan hal tersebut dapat disimpulkan bahwa perangkat RPP dikatakan efektif.

Keterampilan psikomotor yang diamati adalah keterampilan psikomotor menggunakan kertas saring. Ringkasan hasil keterampilan psikomotor seperti Tabel 4.

Tabel 4. Hasil keterampilan psikomotor

\begin{tabular}{lcccc}
\hline \multicolumn{1}{c}{ Indikator } & \multicolumn{4}{c}{ Menggunakan kertas saring } \\
\multicolumn{1}{c}{ Aspek yang diamati } & Rata-rata & Skor maksimal & \% & Kategori \\
\hline Melipat kertas & 4 & 4 & 100 & Sangat Baik \\
Menyimpan kertas saring & 4 & 4 & 100 & Sangat Baik \\
Menuangkan campuran pada corong & 4 & 4 & 100 & Sangat Baik \\
\hline
\end{tabular}

Berdasarkan Tabel 4 aspek yang diamati meliputi melipat kertas, menyimpan kertas saring dan menuangkan campuran pada corong terkategori sangat baik. Berdasarkan hal tersebut dapat disimpulkan bahwa perangkat RPP dikatakan efektif.

Pengamatan perilaku berkarakter peserta didik meliputi disiplin dan tanggung jawab peserta didik terhadap kegiatan selama pembelajaran berlangsung.

\begin{tabular}{ccccccc}
\multicolumn{7}{c}{ Tabel 5. Hasil perilaku berkarakter } \\
\hline Indikator & Disiplin & \multicolumn{4}{c}{ Tanggung jawab } \\
\hline Pertemuan & 1 & 2 & 3 & 1 & 2 & 3 \\
Rata-rata & 3 & 4 & 4 & 4 & 4 & 4 \\
Skor Maksimal & 4 & 4 & 4 & 4 & 4 & 4 \\
$\%$ & $75 \%$ & $100 \%$ & $100 \%$ & $100 \%$ & $100 \%$ & $100 \%$ \\
\hline Kategori & Cukup baik & Sangat baik & Sangat baik & Sangat baik & Sangat baik & Sangat baik \\
\hline
\end{tabular}


Berdasarkan Tabel 5 indikator disiplin selama pembelajaran terkategori sangat baik sedangkan indikator tanggung jawab terkategori sangat baik. Berdasarkan hal tersebut dapat disimpulkan bahwa perangkat RPP dikatakan efektif.

Keterampilan sosial dinilai dari karakter yang muncul pada peserta didik sesuai dengan indikator yang dimiliki yaitu bekerja sama dan menyumbangkan ide. Hasil keterampilan sosial selama kegiatan pembelajaran dapat dilihat pada Tabel 6.

Tabel 6. Hasil keterampilan sosial

\begin{tabular}{ccccccc}
\hline Indikator & \multicolumn{3}{c}{ Bekerjasama } & \multicolumn{3}{c}{ Menyumbangkan ide } \\
\hline Pertemuan & 1 & 2 & 3 & 1 & 2 & 3 \\
Rata-rata & 3 & 3 & 4 & 4 & 4 & 4 \\
Skor Maksimal & 4 & 4 & 4 & 4 & 4 & 4 \\
$\%$ & $75 \%$ & $75 \%$ & $100 \%$ & $100 \%$ & $100 \%$ & $100 \%$ \\
\hline Kategori & Cukup baik & Cukup baik & Sangat baik & Sangat baik & Sangat baik & Sangat baik \\
\hline
\end{tabular}

Berdasarkan Tabel 6 indikator bekerja sama terkategori cukup baik sedangkan indikator menyumbangkan ide terkategori sangat baik. Berdasarkan hal tersebut dapat disimpulkan bahwa perangkat RPP dikatakan efektif.

Penilaian terhadap sikap spiritual dinilai dari karakter yang muncul pada peserta didik sesuai dengan indikator yang dimiliki yaitu rasa syukur. Hasil sikap spiritual selama pembelajaran dapat dilihat pada Tabel 7.

Tabel 7. Hasil sikap spiritual

\begin{tabular}{cccc}
\hline Indikator & \multicolumn{3}{c}{ Rasa Syukur } \\
\hline Pertemuan & 1 & 2 & 3 \\
Rata-rata & 4 & 4 & 4 \\
Skor Maksimal & 4 & 4 & 4 \\
$\%$ & $100 \%$ & $100 \%$ & $100 \%$ \\
\hline Kategori & Sangat baik & Sangat baik & Sangat baik \\
\hline
\end{tabular}

Berdasarkan Tabel 7, rasa syukur terkategori sangat baik dimana sikap peserta didik dalam kegiatan pembelajaran menunjukkan ekspresi wajah penuh rasa syukur, gembira, dan bersemangat atas segala ciptaan Tuhan YME yang bermanfaat bagi kehidupan. Berdasarkan hal tersebut dapat disimpulkan bahwa perangkat RPP dikatakan efektif.

Berdasarkan hasil belajar kognitif, ketuntasan peserta didik pada saat pre-test belum mencapai ketuntasan. Hal ini terjadi dikarenakan peserta didik belum mengikuti pembelajaran pada materi perubahan wujud sebelumnya, sehingga jawaban peserta didik saat pre-test hanya berdasarkan pengetahuan awal atau bahkan perkiraan peserta didik sedangkan hasil post-test terjadi peningkatan dengan ketuntasan sebesar 76\% dan telah mencapai KKM yang ditetapkan sekolah yaitu sebesar 75 . Peningkatan hasil belajar ini disebabkan karena pada saat pretes peserta didik belum memperoleh bahan ajar sehingga ketuntasan klasikal rendah. Post-test dilaksanakan setelah peserta didik memperoleh bahan ajar, sehingga pengetahuan peserta didik terkait topik yang diajarkan meningkat dan hasil belajar pun turut meningkat.

Setyowati (2015) menyatakan perangkat pembelajaran yang memenuhi persyaratan sebagai perangkat pembelajaran yang layak pakai sehingga dapat menunjang tercapainya tujuan pembelajaran. Temuan ini telah memperoleh dukungan melalui penelitian-penelitian sebelumnya. Supasorn dan Lordkam (2014) melaporkan rancangan pembelajaran berbasis inkuiri pada materi pemisahan zat. Hasil penelitian menunjukkan pembelajaran berbasis penyelidikan efektif untuk meningkatkan hasil belajar dan minat peserta didik terhadap pembelajaran sains. Menurut Dewi (2013) melaporkan hasil pengembangan perangkat pembelajaran inkuiri terbimbing dapat meningkatkan hasil belajar peserta didik kategori efektif.

Keterampilan berpikir kritis memberi tekanan kepada proses pembentukan keterampilan memperoleh pengetahuan dan mengkomunikasikan perolehannya. Penelitian yang dilakukan selama tiga kali pertemuan ini aspek keterampilan berpikir kritis yang diamati tiap pertemuan sesuai dengan aktivitas pembelajaran yang dilakukan. Berdasarkan Tabel 3, menunjukkan kemampuan mengkomunikasikan kesimpulan memiliki rata-rata terendah pada setiap LKPD, hal ini tidak berarti peserta didik tidak mampu mengkomunikasikan hasil kesimpulan tetapi lebih disebabkan alokasi waktu yang dise- 
Noorlatifah., Suryajaya., \& Zaini, M. (2021). Keefektifan Perangkat Rencana Pelaksanaan Pembelajaran melalui Penelitian Berbasis Perancangan.

diakan untuk mendiskusikan kesimpulan dalam diskusi kelas sangat terbatas sehingga tidak semua peserta didik berkesempatan memaparkan kesimpulan, bertanya, dan menjawab pertanyaan.

Ural (2016) menyatakan inkuiri terbimbing mampu meningkatkan keterampilan berpikir kritis peserta didik dalam laboratorium. Peserta didik dapat menerapkan pendekatan ilmiah dalam pembelajaran. Penelitian lain yang mendukung adalah dari Harrison (2014) melaporkan dalam penelitiannya tentang strategi guru melakukan penilaian pembelajaran inkuiri dalam proyek sains menyatakan bahwa diperlukan kemampuan guru melakukan penilaian dalam pembelajaran inkuiri, tidak hanya membuat soal-soal formatif tetapi juga dalam hal unjuk kerja dan penilaian langsung karena hal tersebut memungkinkan peserta didik lebih inovatif dalam penyelidikan. Lati dkk., (2012) menyatakan peningkatan prestasi belajar dan keterampilan berpikir dengan menggunakan kegiatan pembelajaran inkuiri tingkat reaksi kimia secara efektif dengan melibatkan peserta didik pada tahap pertama dan sepanjang proses belajar penyelidikan.

Berdasarkan Tabel 4, diperoleh pula keterampilan psikomotor yang telah memenuhi kriteria sangat baik. Pencapaian tersebut, disebabkan oleh peserta didik yang terlibat secara aktif ketika pembelajaran menggunakan perangkat model inkuiri terbimbing dan terintegrasi pendidikan karakter berlangsung serta guru yang telah tepat dalam mengambil peran selama proses pembelajaran berlangsung. Trianto (2011) menjelaskan motivasi dan arahan yang diberikan oleh guru pada pembelajaran inkuiri akan memberikan rangsangan kepada peserta didik untuk terlibat aktif dan bergairah untuk berpikir serta memimpin kegiatan yang dilakukan oleh peserta didik untuk mencapai tujuan yang diharapkan. Sehingga keterampilan psikomotorik yang diharapkan, dapat terlihat secara optimal dan berkembang dari pertemuan satu ke pertemuan berikutnya.

Sanjaya (2006) menyatakan model inkuiri merupakan pengalaman yang diperoleh peserta didik sebagai hasil dari aktivitas sendiri. Peserta didik mengalami dan merasakan sendiri segala sesuatu yang berhubungan dengan pencapaian tujuan. Peserta didik berhubungan langsung dengan objek yang hendak dipelajari tanpa menggunakan perantara.

Perkembangan perilaku berkarakter disiplin peserta didik di SMPN 22 Banjarmasin sangat baik meskipun tidak dapat dinilai dengan cepat. Namun perkembangan karakter disiplin mengalami peningkatan tiap pertemuan. Melalui pelajaran IPA peserta didik dituntut untuk mendalami pendidikan karakter, khususnya karakter disiplin. Jadi mau tidak mau semua peserta didik harus mempelajari dan mengamalkan dalam kehidupan sehari-hari baik di luar sekolah maupun di dalam sekolah.

Peningkatan perilaku berkarakter tanggung jawab mengalami peningkatan ke arah yang lebih baik. Peningkatan nilai karakter tanggung jawab didapatkan karena karakter ini selalu dilatihkan kepada peserta didik baik pada tahap awal melalui kegiatan pengamatan selama menggunakan model inkuiri terbimbing, maupun pada tahap menganalisis data hasil percobaan. Rahayu dkk. (2020) dalam penelitiannya juga menyatakan peserta didik dapat melaksanakan tugas dan kewajibannya sebagaimana yang seharusnya dilakukan dan tidak mudah ketergantungan pada orang lain dalam menyelesaikan tugas.

Pencapaian tersebut, disebabkan oleh guru memberikan teladan yang baik sebagai metode tambahan untuk mendidik karakter peserta didik. Cara guru menyelesaikan masalah secara adil, mengungkapkan pendapat, menjawab pertanyaan, menghargai pendapat peserta didik, menggunakan bahasa yang santun. Flournoy (2009) menyatakan fasilitas peserta didik dengan lingkungan yang nyaman, maka akan mengembangkan karakter peserta didik dan mampu meningkatkan prestasi belajar. Hal ini dikarenakan lingkungan yang nyaman akan mengubah pola perilaku peserta didik dalam belajar secara positif. Lingkungan yang nyaman tersebut, dapat diciptakan di rumah maupun di sekolah. Brown (2008) menyatakan tidak masalah bagaimana metode atau cara yang tepat dalam mendidik karakter peserta didik, menurutnya dengan cara apa pun, pendidikan karakter akan mempengaruhi perilaku peserta didik. Jannah (2012) menyatakan pada praktikum inkuiri terbimbing dapat meningkatkan nilai karakter mandiri, disiplin, kerjasama, dan rasa ingin tahu.

Keterampilan sosial (bekerjasama dan menyumbang ide) tercermin ketika peserta didik terlibat dalam kegiatan diskusi, percobaan/penyelidikan, dan pembuatan hasil karya. Selama pembelajaran menunjukkan aktivitas peserta didik lebih banyak melakukan diskusi dan bekerja sama dengan temannya. Peserta didik juga sangat menghargai teman-temannya yang memberikan ide atau pendapat. Hal inilah yang menjadi harapan selanjutnya untuk melatih peserta didik untuk berbicara didepan umum, memberanikan diri dalam memberikan ide atau tanggapan balik. Sehingga nantinya akan muncul suasana yang lebih baik dalam berdiskusi dan secara terbuka. 
Sesuai hasil analisis tersebut di atas menunjukkan telah terjadi interaksi dalam proses pembelajaran walaupun masih lebih banyak dalam kelompok kecil dan peserta didik juga saling menghargai teman-temanya dalam memberikan pendapat. Hal ini juga dapat dikatakan bahwa guru tidak menjadi sumber pengetahuan tetapi lebih bersifat sebagai fasilitator, sedangkan peserta didik lebih banyak menemukan sendiri hasil belajarnya.

Keith (2009) menyatakan peranan pembelajaran dalam meningkatkan kemampuan komunikasi dan penalaran menjadi sangat sentral. Dalam proses pembelajaran masih banyak ditemukan kegagalan karena guru tidak memberikan pengalaman penalaran sehingga peserta didik tidak mampu mengemukakan pendapat dan memberikan penjelasan. Menurut Nur (2011) menyatakan keterampilan sosial dapat dicapai apabila setiap anggota kelompok dapat berperan serta dan mampu bekerja sama dengan baik tanpa terfokus pada satu atau dua orang saja.

Pada pembelajaran ini pembentukan karakter dikatakan berhasil, karena secara keseluruhan peserta mendapatkan skor $100 \%$. Hal ini penting dimplimentasikan untuk melatih karakter religi peserta didik sejak dini. Pembentukan karakter tidak bisa dilakukan dalam waktu singkat, tetapi indikator perilaku dapat dideteksi secara dini oleh guru, terutama dalam penyelesaian pendidikan, dan kehidupannya dengan masyarakat kelak (Fahmi, 2014).

Agustini (2016) menyatakan sikap peserta didik dalam kegiatan pembelajaran menunjukkan ekspresi wajah penuh rasa syukur, gembira, dan bersemangat atas segala ciptaan Tuhan YME yang bermanfaat bagi kehidupan. Karena dalam proses pembelajaran dengan pendekatan lingkungan peserta didik dibawa, melihat, dan mengamati langsung apa yang terjadi di lingkungan, serta merasakan betapa besar dan agungnya sang pencipta. Hal ini akan menumbuhkan dan menambahkan rasa syukur kepada sang pencipta.

\section{SIMPULAN}

Perangkat RPP menggunakan model inkuiri terbimbing topik perubahan wujud tergolong efektif meliputi hasil belajar peserta didik yang sudah tuntas sebanyak 23 orang dengan persentase ketuntasan sebesar $76 \%$ dan telah mencapai KKM yang ditetapkan sekolah yaitu sebesar 75, keterampilan berpikir kritis peserta didik meliputi merumuskan masalah, membuat hipotesis, merancang percobaan, melakukan percobaan untuk memperoleh informasi, mengumpulkan data dan menganalisis data, serta membuat kesimpulan terkategori sangat baik, keterampilan psikomotor peserta didik menggunakan kertas saring ada tiga aspek yang diamati meliputi melipat kertas, menyimpan kertas saring dan menuangkan campuran pada corong terkategori sangat baik, perilaku berkarakter meliputi aspek disiplin terkategori sangat baik dan aspek tanggung jawab terkategori sangat baik, keterampilan sosial meliputi aspek bekerja sama terkategori cukup baik dan aspek menyumbangkan ide terkategori sangat baik, dan sikap spiritual rasa syukur terkategori sangat baik.

\section{DAFTAR PUSTAKA}

Af'idayani, N., Setiadi, I., \& Fahmi. (2018). The Effect of Inquiry Model on Science Process Skills and Learning Outcomes. European Journal of Education Studies, 4 (12), 177-182. Doi: 10.5281/zenodo.1344846.

Agustini, M. (2016). Pengembangan Perangkat Pembelajaran dengan Pendekatan Lingkungan Materi Ekosistem di MAN 1 Barabai. Tesis. Program Studi Magister Pendidikan Biologi Universitas Lambung Mangkurat.

Brown, C. (2008). Character Education and its Impact on Student Behavior. ProQuest Education Journal. $33(2)$.

Dewi, K. (2013). Pengembangan Perangkat Pembelajaran IPA Terpadu dengan Seting Inkuiri Terbimbing untuk Meningkatkan Pemahaman Konsep dan Kinerja Ilmiah Peserta Didik. e-Journal Program Pascasarjana Universitas Pendidikan Ganesha Program Studi IPA.

Fahmi., Setiadi, I., Elmawati, D., \& Sunardi. (2019). Discovery Learning Method for Training Critical Thinking Skills of Students. European Journal of Education Studies, 6 (3), 342-351. Doi: 10.5281/zenodo.3345924.

Fahmi. (2014). Pendidikan Karakter Berbasis Akhlak Mulia melalui Pengamalan terhadap Al Qur'an. Proceeding International Seminar on Character Education. FKIP Unlam Press.

Fahmi. (2016). Strategi Pembelajaran Contextual Teaching and Learning untuk Meningkatkan Keterampilan Berpikir Tingkat Tinggi. Prosiding Seminar Nasional Pendidikan IPA "Mengem- 
Noorlatifah., Suryajaya., \& Zaini, M. (2021). Keefektifan Perangkat Rencana Pelaksanaan Pembelajaran melalui Penelitian Berbasis Perancangan.

bangkan Keterampilan Berpikir Tingkat Tinggi Melalui Pembelajaran IPA”. S2 IPA Unlam Press. Banjarmasin, Indonesia. ISBN. 978-602-60213-0-4

Flournoy, T. (2009). Character Education and the Perceived Impacton Student Academic Achievement. ProQuest Education Journal, 35 (4).

Harrison, C. (2014). Asessment of Inquiry Skills in the SAILS Project. ERIC Science Educational Journal International.

Jannah, M. (2012). Pengembangan Perangkat Pembelajaran Berorientasi Nilai Karakter Melalui Inkuiri Terbimbing Materi Cahaya pada Peserta Didik Kelas VIII Sekolah Menengah Pertama. Journal of Innovative Science Education. 1 (1), 60.

Kemendikbud. (2013). Peraturan Menteri Pendidikan dan Kebudayaan Nomor 65 Tahun 2013. Jakarta: Kemendikbud.

Kemendikbud. (2014). Peraturan Menteri Pendidikan dan Kebudayaan Nomor 58 Tahun 2014. Jakarta: Kemendikbud.

Keith, J. (2009). Providing a Foundation for Deductive Reasoning Students Interpretations When Using Dynamic Geometry Software and Their Evolving Mathematical Explanitions. Centre for Research in Mathematics Education University of Southampton.

Khaerani, S.K., Utami, S.D., \& Mursali, S. (2020). Pengembangan Perangkat Pembelajaran IPA Berbasis Kearifan Lokal untuk Meningkatkan Hasil Belajar Kognitif Siswa. Journal of Banua Science Education (JBSE), 1 (1), 35-42. E- ISSN: 2745-7222. Doi: 10.20527/jbse.v1i1.2. http://jbse.ulm.ac.id/index.php/JBSE/issue/view/2

Lati, W., Supasorn, S., \& Promarak, V. (2012). Enhancement of Learning Achievement and Integrated Science Process Skills Using Science Inquiry Learning Activities of Chemical Reaction Rates. Procedia-Social and Behavioral Sciences 46, 4471-4475.

Nur, M. (2011). Model Pembelajaran Berdasarkan Masalah. Surabaya: UNESA Press.

Rahayu, A.B., Hadi, S., Istyadji, M., Zaini, M., Sholahuddin, A., \& Fahmi. (2018). Development of Guided Inquiry Based Learning Devices to Improve Student Learning Outcomes in Science Materials in Middle School. European Journal of Alternative Education Studies, 3 (2), 107-117. Doi: 10.5281/zenodo.2261027.

Rahmawati, I., Mastuang., Suyidno., \& Sunarti, T. (2020). Kelayakan Bahan Ajar Elastisitas dan Hukum Hooke Berbasis Inkuiri Terbimbing untuk Melatihkan Keterampilan Proses Sains Peserta Didik. Journal of Banua Science Education (JBSE), 1 (1), 21-28. E- ISSN: 2745-7222. Doi: 10.20527/jbse.v1i1.1. http://jbse.ulm.ac.id/index.php/JBSE/issue/view/2

Sanjaya, W. (2006). Strategi Pembelajaran Berorientasi Standar Proses Pendidikan. Jakarta: Kencana Prenada Media.

Setyowati, T. (2015). Pengembangan Perangkat Pembelajaran IPA SMP Menggunakan Model Inkuiri Topik Klasifikasi Makhluk Hidup. Tesis. Magister Pendidikan Biologi. Unlam. Banjarmasin.

Supasorn, S \& Lordkam, A. (2013). Enhancement of Grade 7 Students Learning Achievement of the Matter Separation by Using Inquiry Learning Activities. Procedia-Social and Behavioral Sciences, 116, 739-743.

Tessmer, M. (1998). Planning and Conducting Formative Evaluations. London: Kogan Page.

Trianto. (2011). Mendesain Model Pembelajaran Inovatif-Progresif: Konsep, Landasan, dan Implementasinya pada Kurikulum Tingkat Satuan Pendidikan (KTSP). Jakarta: Kencana.

Ural, E. (2016). The Effect of Guided-Inquiry Laboratory Experiments on Science Education Students Chemistry Laboratory Attitudes, Anxiety and Achievement. Journal of Education and Training Studies, 4 (4). 